\title{
From Vitalism to Animal Magnetism: The Mesmerist Experiments of Dr Jean-Emmanuel Gilibert (1741-1814)
}

\author{
Arnaud Parent \\ Institute of Humanities, \\ Mykolas Romeris University \\ Ateities g. 20, \\ Vilnius LT-08303, Lithuania \\ E-mail: arnaudparent@hotmail.com
}

\begin{abstract}
In 1766, the German physician Franz Anton Mesmer (1734-1815) presented at the faculty of medicine in Vienna his doctoral thesis On the Influence of the Planets on the Human Body (De planetarum influxu in corpus humanum), which was inspired by the De imperio solis ac lunae (1704), a work by Richard Mead (1673-1754), a disciple of Newton. In the thesis, Mesmer asserted that the cosmos and bodies floated in a universal fluid, which he called 'animal magnetism'. Diseases resulted from disorders of animal magnetism within individuals, and he proposed brand-new treatments to cure these disorders. Around 1775, Mesmer sent his small monograph to different academies of science in Europe and to selected scientists. Only the Berlin Academy answered, but dismissed his work. In February 1778, he
\end{abstract} arrived in Paris, where he began to cure patients.

A French physician from Lyon, Dr Jean-Emmanuel Gilibert (1741-1814), started to show interest in this mesmerist doctrine. Gilibert was a renowned physician and botanist. In 1775, he went to the Grand Duchy of Lithuania where he founded a medical school and a hospital in the town of Grodno (in present-day Belarus), where he worked from 1775 until 1781. He then moved to Vilnius to teach natural history at the Principal School of the Grand Duchy of Lithuania (Schola Princeps Magni Ducatus Lithuaniae, today Vilnius University), before returning to France in 1783. Gilibert was a strong believer in vitalism, a medical doctrine which stated that the physician should intervene as little as possible in healing the sick and letting nature do the healing. He saw animal magnetism as an expression of vitalism and carried out numerous experiments, which he described in letters addressed to his friend Antoine- 
François Prost de Royer (1729-1784). In 1784, Gilibert published these letters in his Outline on Animal Magnetism, or findings of the observations made in Lyon about this new agent (Apperçu sur le magnétisme animal, ou résultat des observations faites à Lyon sur ce nouvel agent). These letters are of utmost interest because they show how a scientist of the last quarter of the 18 th century regarded science and scientific research, at a time when science and pseudoscience were still intermingled. This article will present the way in which Gilibert devised and carried out his mesmerist experiments, and the conclusions he reached.

Keywords: 18th century, experimentations, Jean-Emmanuel Gilibert, mesmerism, vitalism

"I have learned to adopt facts and inductions, only after having analyzed, compared and weighed them on the most severe scales of doubt. "'

Dr Jean-Emmanuel Gilibert

\section{Introduction}

In 1968, Robert Darnton published his still unequaled study on the mesmerist movement in France on the eve of the French Revolution (Darnton, 1968). Since then, numerous American and British scholars published important studies on French medicine in the 18th century, which were useful to their French colleagues (Wilson, 1992; Williams, 1997; Brockliss \& Jones, 1997; Vila, 2003). A further contribution to these studies in the English language on French medical history is this paper on the mesmerist experiments carried out by the French physician Dr Jean-Emmanuel Gilibert (1741-1814). ${ }^{2}$ The experiments are all the more interesting because Gilibert, unlike most of the people that carried out experiments on magnetism at that time, was a scientist, but also because he came to animal magnetism via medical vitalism.

In 1766, the German physician Franz Anton Mesmer (1734-1815), presented at the faculty of medicine in Vienna his doctoral thesis On the Influence of the

1 "jai appris à n’adopter les faits et les inductions, qu'après les avoir analysés, comparés, et pesés dans la balance du doute le plus sévere" (Gilibert, 1784, p. 2). The original French spelling of the time has been retained.

2 I would like to thank Dr Ramūnas Kondratas (from the Vilnius University) for his insights, advice and comments. 


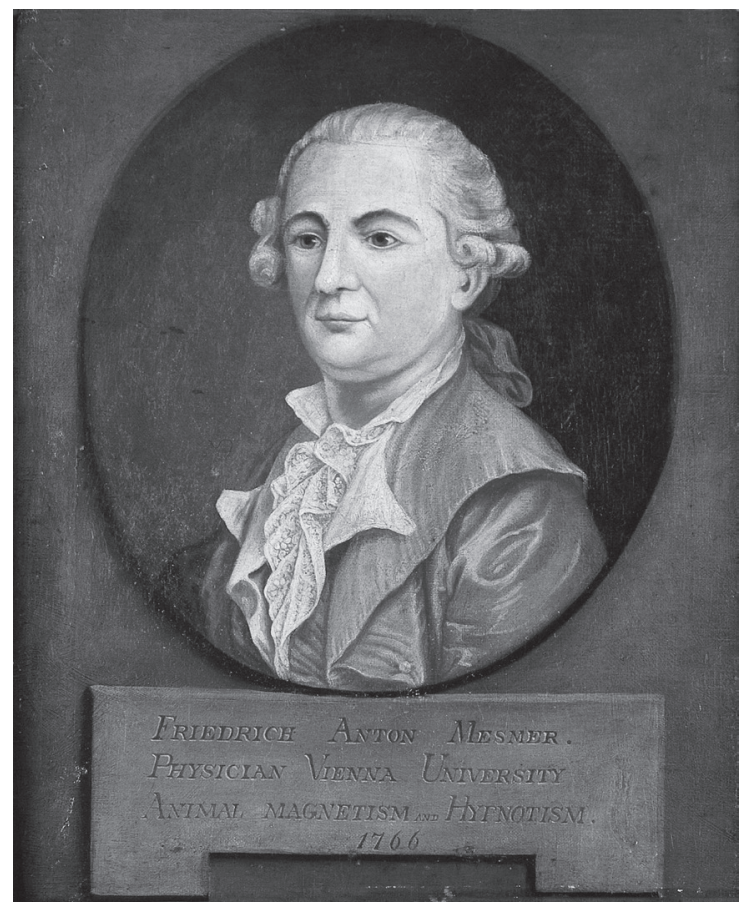

Figure 1. Portrait of Doctor Franz Anton Mesmer (1734-1815). Unknown painter.

(Wellcome Library no. 45736i)

Planets on the Human Body (De planetarum influxu in corpus humanum), which was inspired by De imperio solis ac lunae (1704), a work written by Richard Mead (1673-1754), a disciple of Newton (1643-1727) (Spiquel, 1997, p. 33). In the thesis, Mesmer claimed that the cosmos and bodies floated in a universal fluid, which he called 'animal magnetism'. Diseases resulted from disorders of animal magnetism within individuals, and he proposed brand-new treatments to cure these disorders. Indeed, Mesmer had been strongly influenced by Johann Joseph Gassner (1727-1779), an Austrian Catholic priest, exorcist and healer, whom he met in the years 1774-1775 (Lapassade, 1983, p. 78). Around 1775, Mesmer sent his small monograph (88 pages with 27 appended Propositions) to different academies of science in Europe and selected scientists. Only the Berlin Academy answered, but dismissed his ideas (Lanska \& Lanska, 2007, p. 305).

In February 1778, Mesmer arrived in Paris, where he was welcomed by the locals, who were always eager for novelties, and began to cure patients. Basically, 
Mesmer healed them by laying the tip of his fingers on the hypochondrium, ${ }^{3}$ the pit of the stomach or the plexus, always following the nerves (Doppet, 1784, p. 44; Brack, 1784, p. 12; Azouvi, 1976, p. 126). The treatment involved the use of some devices, such as a tub filled with water and crushed glass, covered with a lid, from which extended hooked iron rods that were applied on the diseased parts of the patient's body. There were also mirrors (to reflect the magnetic energy toward the patient), a knotless rope (to link the patients between them), and particular sounds (produced by a glass harmonica, a musical instrument invented by Benjamin Franklin, which incorporated a series of graduated revolving glass bowls made to vibrate when touched with wet fingertips).

Although he used magnetism in his treatments, Mesmer actually never questioned his doctrine. The experiments were carried on by his followers, who tried to define the nature of magnetism and explored its applications (McGrew \& McGrew, 1985, pp. 199-200). In so doing, they ultimately, in the 19th and 20th centuries, gave way to the birth of hypnotism, psychology, psychiatry, psychosomatic medicine, group therapy and psychoanalysis (McGrew \& McGrew, 1985, p. 197). Actually, as Roderick and Margaret McGrew have observed, Mesmer may be considered the "true blind prophet", who "pointed out roads he could not see, which led to destinations whose existence he never suspected" (McGrew \& McGrew, 1985, p. 200).

This new way of healing aroused interest all over France (Lanska \& Lanska, 2007 , p. 305). Some believed it to be a fraud, others saw it as a wonderful new way of healing, and began to magnetize themselves. Mesmerism became such a craze that cartoonists and dramatists satirized it (Inchbald, 1789). Nevertheless, such enthusiasm prompted strong criticism from the medical institutions. In 1784 , in order to determine whether the treatments using animal magnetism were effective or fake, King Louis XVI (1754-1793) launched two commissions: one composed of members chosen from the Royal Academy of Sciences (five commissioners) and the Paris Faculty of Medicine (four commissioners), and one made up of members of the Royal Society of Medicine (Darnton, 1968, pp. 62-64). On 4 September 1784, the first commission submitted its report to the King. It concluded that there was no evidence for Mesmer's fluid, and that whatever the benefit the treatment produced, it could be attributed to "imagination" (Bailly et al., 1784, pp. 9, 11). The second commission arrived at

3 Hypochondrium, or the hypochondriac area: "the part of the abdomen in the upper zone on both sides of the epigastric region and beneath the cartilages of the lower ribs" (Mosby's Medical Dictionary, 2017, p. 882). 
the same conclusion (Poissonnier et al., 1784). It has to be noted that Antoine Laurent de Jussieu (1748-1836), a member of this second commission, issued his own report in which he suggested that the magnetism phenomenon could be worth further investigation (Jussieu, 1784). However, whatever the results and conclusions made about the conducted experiments, they were not pointless, for they showed the power of imagination, that is, the influence of the "moral" on the "physical". Additionally, the commissioners observed the potentiality of a magnetizer to capture the imagination of a magnetized person and make her believe anything by shaking up her nervous system. The commissioners realised the dangers that such a phenomenon could lead to and, as "philosophers" (i.e., the learned persons who have to handle facts critically) expressed the need to further study this phenomenon in order to prevent it. ${ }^{5}$ Also, on 11 August, Jean Bailly (1736-1793), member of the first commission, had handed over a secret report to Louis XVI. In this report, Bailly acknowledged the reality of mesmerist fluid but he was also disturbed by its effects on patients, especially on women who lose control of themselves. That is, mesmerist sessions were a moral problem, and women had to be deterred from participating in magnetism sessions (Chertok \& Stengers, 1992, p. 2).

The reports released by the commissions fueled the controversies surrounding animal magnetism. Some, like Antoine-François Prost de Royer (1729-1784), ${ }^{6} \mathrm{a}$ respected high magistrate in Lyons, wished to make up his mind about mesmerist ideas and asked his friend, the physician Jean-Emmanuel Gilibert, to give his opinion on the phenomenon. At that time Dr Gilibert was already a renowned physician and botanist. He had come to the Grand Duchy of Lithuania to found a school of medicine and a hospital in the town of Grodno (today's Гродна in Belarus), where he worked from 1775 until 1781 . He then moved to Vilnius to

"une science encore neuve, celle de l'influence du moral sur le physique [...]." (Bailly et al., 1784, p. 11)

5 "l'homme peut agir sur l'homme, à tous momens, et presque à volonté, en frappant son imagination" (Bailly et al., 1784, p. 14); "l'homme a le pouvoir d'agir sur son semblable, d'ébranler le système de ses nerfs, et de lui imprimer des convulsions [...]. Action presque toujours dangereuse, que l'on peut observer en philosophe, et quil n'est bon de connoître que pour en prévenir les effets [...]." (Bailly, 1784, p. 15)

6 Antoine François Prost de Royer (1729-1784) was an administrator of hospitals, a member of the city council of Lyons during the years 1773-1774, and president of the chamber of commerce. In 1772, he became the head of the police of the town. He has written Lettre sur l'administration des hôpitaux, Lyon, 1765; Mémoires sur la conservation des enfants, Lyon, 1778; Dictionnaire de jurisprudence et des arrêts, ou jurisprudence universelle des parlements de France et autres tribunaux, t. i-v, 1784. (Biographie universelle, ancienne et moderne, t. xxxvi, 1823, pp. 147-149; Barou du Soleil, 1784; Dictionnaire de jurisprudence et des arrêts, tome troisième, 1783, pp. 426-427). 


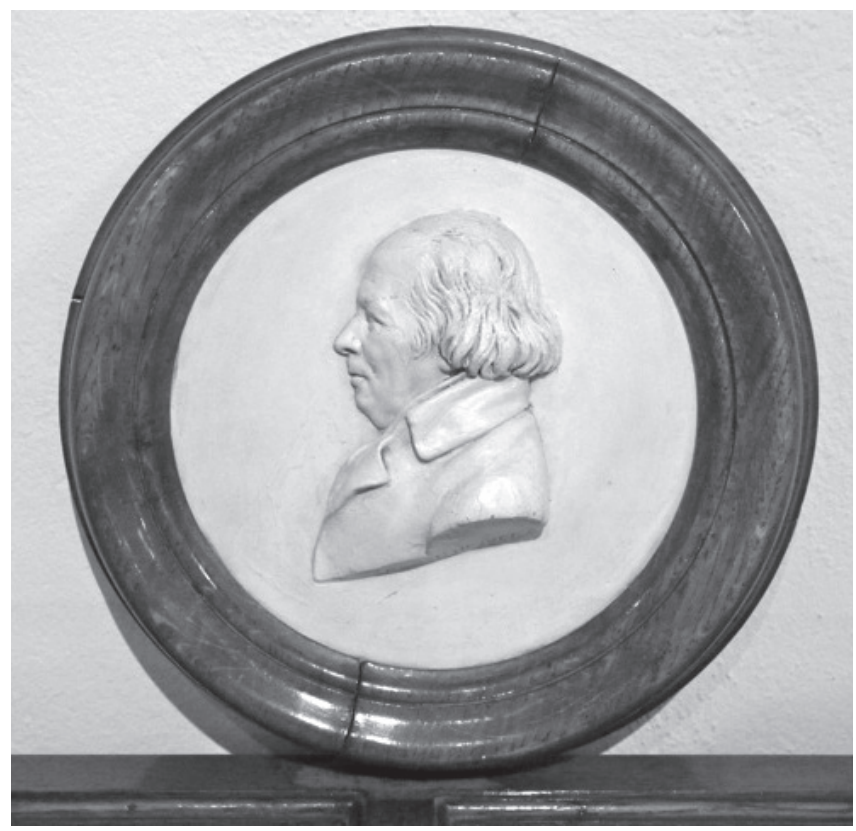

Figure 2. Dr Jean-Emmanuel Gilibert (1741-1814). Medallion made by Joseph Chinard (1756-1813). Courtesy of Musée d'Histoire de la Médecine et de la Pharmacie, Lyon.

teach natural history at the Principal School of the Grand Duchy of Lithuania (Schola Princeps Magni Ducatus Lithuaniae, today Vilnius University), before going back to France in $1783 .{ }^{7}$ Gilibert was a strong believer in medical vitalism, a medical doctrine, which stated that the physician should intervene as little as possible in healing the sick, letting nature do the healing. ${ }^{8}$

Gilibert, eager to learn about any scientific novelty, was all the more interested in animal magnetism that he saw it as an expression of vitalism. On 14 July, 1784 , he wrote to Royer that animal magnetism "is possibly the most important scientific topic of the day" (Gilibert, 1784, p. i). ${ }^{9}$ He carried out various experiments, which he described in letters addressed to Antoine-François Prost

7 On Dr Jean-Emmanuel Gilibert's work in the Grand Duchy of Lithuania, see Sławiński, 1925, pp. 8-45; Daszkiewicz, 1995; Ignatovich, 2011, pp. 85-90; Parent, 2015, pp. 122-146.

8 On the development of vitalism in eighteenth-century France, see Rey, 2000; Williams, 2003. On Dr Gilibert and medical vitalism, see Parent, 2016.

9 "Rien dans ce moment n'est peut être plus intéressant, que ce qui a rapport au magnétisme animal" (Gilibert, 1784, p. i) 
de Royer (1729-1784) that were published subsequently: Outline on Animal Magnetism, or findings of the observations made in Lyons about this new agent (in French: Apperçu sur le magnétisme animal, ou résultat des observations faites à Lyon sur ce nouvel agent). This work was among many others published in France in 1784, after the appearance of the two official commission reports on mesmerism.

Gilibert's letters are of utmost interest because they show what a scientist in the last quarter of the 18th century thought to be science, when science and pseudoscience ${ }^{10}$ were still intermingled. However, it has to be reminded, as science historian Jacques Roger has stated, that if today's historians make a difference between "true" and "false" sciences, such differentiation, however relevant, may hamper the understanding of scientific development in the past. ${ }^{11}$ Such has been the case of phlogiston, for instance, in the field of chemistry. ${ }^{12}$

\section{Purpose of the study}

Dr Gilibert's main purposes were, first, to check that animal magnetism does not result from imagination, and, second, if it exists, how it affects the human body. Gilibert stressed that he did not carry on any experiments on sick people, for he first wanted to test the effects of magnetism on healthy people after numerous experiments. ${ }^{13}$ Nevertheless, while Gilibert does not mention the number of experiments he carried out, or the number of persons on whom he carried these out, he presents the trial-and-error methods he used, and their outcome.

10 Pseudoscience is a system of thought or a theory that is not formed in a scientific way (Cambridge Dictionary, n.d.)

11 "S'ils éprouvent rarement le besoin de définir la science, les scientifiques font au moins une distinction claire entre vraies et fausses sciences. [...] Mais que vaut cette distinction si on la projette dans le passé? [...] Si légitime qu'elle soit aujourd'hui, la distinction vraie science-fausse science risque de gêner l'historien." (Roger, 1993, pp. xxi, xxv)

12 In 1718, the German chemist and physician Georg-Ernst Stahl (1660-1734) coined the term phlogiston, using the Greek root phlogos, meaning flame. Stahl argued that metals were composed of calx and phlogiston. When a metal was heated, phlogiston was released into the atmosphere and left behind the calx. It is not possible to breathe in phlogisticated air, but according to the phlogiston theory, atmosphere does not get saturated with phlogiston for plants to absorb or fix it from the atmosphere, returning it to flammable wood. Antoine-Laurent Lavoisier, in his Traité élémentaire de Chimie (Paris, 1789), gave the phlogiston theory the death blow (Ede \& Cormack, 2017, pp. 198-2004; Vihalemm, 2019, pp. 88-100).

13 "Je ne vous parlerai point des effets du magnétisme sur les malades, vu que je me suis fait une loi de n'employer cet agent, pour le traitement des maladies, qu'après mêtre assuré, par une multitude d'expériences, de tout ce qu'il peut produire sur les corps sains, ou à-peu-près considérés comme tels." (Gilibert, 1784, pp. 22-23) 


\section{Materials and methods}

Using Giliberts' letters and looking at the scientific approach that he followed we will hereafter investigate: (1) animal magnetism as an expression of vitalism; (2) Gilibert's experiments with animal magnetism; and (3) his conclusions about his experiments.

\section{ANIMAL MAGNETISM AS AN EXPRESSION OF VITALISM}

Dr Gilibert was an enthusiastic proponent of medical vitalism since the very beginning of his career as a physician (his doctoral thesis in medicine was dedicated to this theme). In his Outline on Animal Magnetism, he asserts that nature alone cures most of the curable diseases (Gilibert, 1784, p. 49). Gilibert claims having accomplished quite a number of successful cures without any active remedy. If he expresses regrets, it is about having ordered some remedies at the request of patients' relatives, friends, or of some other physicians, which had turned out to be useless. ${ }^{14}$ Indeed, Gilibert is so confident in the power of nature that, like the English physician Thomas Sydenham (1624-1689), whom he quotes, he believes that the vital principle most often acts so strongly that the physician has to moderate it. ${ }^{15}$

Gilibert was therefore pleased by the status attributed to nature in the mesmerist conceptions of healing. In his Memorandum on the Discovery of Animal Magnetism, Mesmer states that

in all times, we have seen diseases that worsen or improve with or without the relief of medicine, using different systems and the most opposite methods. These considerations have led me to believe that there exists in nature a universally acting principle, which, independently from us, operates what we vaguely attribute to the art of the practitioner and to nature. ${ }^{16}$

14 "j'appris à ne pas douter de l'énergie de la nature, à lui abandonner la plus forte partie de l'ouvrage, me réservant seulement de modérer ses efforts, ou de ranimer ses forces sur un très petit nombre de remèdes : si j'ai quelque reproche à me faire, ce n'est pas d'avoir suspendu les remèdes, mais d'en avoir ordonné quelquefois d'inutiles, entraîné par les sollicitations des parens, des amis, ou des gens de l'art même." (Gilibert, 1784, p. 51)

15 "Je suis convaincu, par ma propre expérience, et Sydenham l'avoit annoncé de cent manières, que, le plus souvent, ce principe vital où la nature agit avec trop d'énergie, quil faut sans cesse le modérer, diminuer sa trop grande force; que nous sommes rarement avertis de le ranimer" (Gilibert, 1784, p. 71).

16 "Aussi a-t-on vu, de tous les temps, les maladies s'aggraver et se guérir avec et sans le secours de la médecine, d'après différens systèmes et les méthodes les plus opposées. Ces considérations ne m'ont pas permis de douter qu'il n'existe dans la Nature un principe universellement agissant, et qui, indépendamment de nous, opère ce que nous attribuons vaguement à l'Art et à la nature." (Mesmer, 1779 , p. 11) 
Hence, "nature offers a universal way to cure people and preserve life". ${ }^{17}$ Charles d'Eslon (1750-1786), a prominent physician and a follower of Mesmer, agrees that "giving back to Nature its real course is the only medicine that may exist". ${ }^{18}$ He also specifies that Mesmer, who heals by creating crises in his patients, does nothing more than provoke or assist the efforts of nature. ${ }^{19}$ Nicolas Bergasse (1750-1832), another enthusiastic follower of Mesmer, writes: "it is wrong that we have cured people, Nature on our side always did, in spite of us [...] so it is always animal magnetism that heals" ${ }^{20}$ For Mesmer and his disciples, the link between nature and animal magnetism is obvious. Given Gilibert's indefatigable trust in vitalism, animal magnetism could only be attractive to him.

Finally, it is worth adding that even the members of the abovementioned first commission reasserted the significant role of nature in healing, thus making it even more difficult to assess the role of magnetism itself in the treatment:

Nature acts at the same time as the remedy. We don't know if the relief results from the remedy or Nature. Nature sometimes heals without remedy. How one may be convinced of the existence of an invisible remedy, when Nature is capable of healing without it? We then could only witness the physical action of the fluid, operating on the momentary changes of the organism. ${ }^{21}$

When the ideas of mesmerism began to spread in France, Gilibert retrospectively made a connection with situations he had observed in the past. Thus, he remembered an event which had happened in 1772 in Lyons. At her arrival in a convent, a young lady was seized with such strong convulsions that she was suffocating. A handmaid decided to call a gardener, who came and put his hand under the lady's chin, touched her neck and got down to the epigastrium. The spasms ceased and the woman felt much better. Dr Gilibert was not in the convent when it happened, but he was there when the lady began to convulse for the second time. Gilibert called the gardener and saw how, once again, he was able to stop

17 "la nature offre un moyen universel de guérir et de préserver les hommes" (Mesmer, 1779, p. vi).

18 "Rendre à la nature son véritable cours, est la seule médicine qui puisse exister." (d'Eslon, 1785, p. 35)

19 "M. Mesmer n'entend guérir qu'à l'aide des crises, c'est-à-dire, en secondant ou en provoquant les efforts de la nature." (d'Eslon, 1785, p. 36)

20 "il est faux que nous ayons jamais guéri personne; [...] c'est la Nature qui a toujours guéri à côté de nous et malgré nous [...] c'est donc toujours le Magnétisme animal qui guérit [...]." (Bergasse, 1781, pp. 29-30)

21 "La Nature agit en même temps que le remède; on ne sait si le soulagement appartient au remède ou à la Nature. La Nature guérit quelquefois sans remède; comment se convaincre de l'existence d'un remède invisible, par des guérisons que la Nature peut opérer sans lui? Nous avons donc été forcés de nous borner à observer l'action physique du fluide, opérant sur l'économie animale des changemens momentanés." (Bailly et al., 1784, p. 6) 
the convulsions. He was surprised and admitted that it could not be scientifically explained. After this event, he began to calm hysterical convulsions the way the gardener did, making downward frictions on the limbs, passing the hands on the neck and the chest, often with a successful result (Gilibert, 1784, pp. 5-6).

Gilibert claimed that he himself benefitted from such treatments. In 1775, when he arrived in Grodno, he quickly realized that Lithuanian climate "was not suitable" for him, and in the winter of 1776-1777 he suffered from fevers, heart palpitations, spasms, and cough so harsh that he often lost consciousness. His health deteriorated so much that he became extremely weak, with "the pale complexion of a corpse" (Gilibert, 1784, p. 6). But he noticed that the touches of some people could be beneficial, or not (Gilibert, 1784, p. 7). These observations amazed him, although he was unable to explain these in medical terms. ${ }^{22}$ The general enthusiasm for mesmerism in France granted Gilibert the opportunity to look deeper into the unexplained phenomena that he had witnessed.

\section{GILIBERT'S EXPERIMENTS WITH ANIMAL MAGNETISM}

Dr Gilibert admitted that at first he was skeptical about mesmerism. "At first glance, mesmerism was to me a charlatanry,"23 he wrote, but because it was such a brand new phenomenon, he thought that numerous experiments needed to be made (Gilibert, 1784, p. iii): "darkness still covers its birth, an obscure veil seems to have been put by nature on what is the most important for us to know, hides from our eyes a phenomenon weak in its origin, but with powerful effects". ${ }^{24}$ Gilibert believed that these experiments were worth doing, for they could lead to direct applications in curing the ill: "The infirmities of man are so great, and the means to relieve them so weak that I believe I do useful work for the public by offering them the beneficial researches of a man whose happiness resides in that of his fellow men." ${ }^{25}$ Such a purpose was in accordance with Mesmer, who saw himself as a scientist who had discovered a tremendous natural secret which he wanted to use to humanity's benefit (McGrew \& McGrew, 1985, p. 199).

22 "Tous ces faits mont long-tems occupé, mais ne trouvant aucune analogie sûre pour les lier avec les phénomènes généraux de la médecine clinique, je les avois laissés flottants autour des connoissances réelles $[\ldots] . . "(G i l i b e r t, 1784$, p. 7$)$

23 "Le mesmérisme, au premier coup-d'œil, m’a paru une charlatanerie : examiné de plus près, il m'a offert des effets incontestables [...]." (Gilibert, 1784, p. 63)

24 "les ténèbres couvrent encore sa naissance, un voile obscur, et que la nature semble n'avoir jetté que sur ce quil nous importe le plus de connoitre; dérobe à nos yeux un agent aussi foible dans son origine, que puissant dans ses effets [...]." (Gilibert, 1784, p. i)

25 "Les infirmités de l'homme sont si grandes, et les moyens pour le soulager si foibles, que je crois travailler utilement pour le public, en lui offrant les recherches bienfaisantes d'un homme qui fait consister son bonheur dans celui de ses semblables [...]." (Gilibert, 1784, pp. iii-iv) 


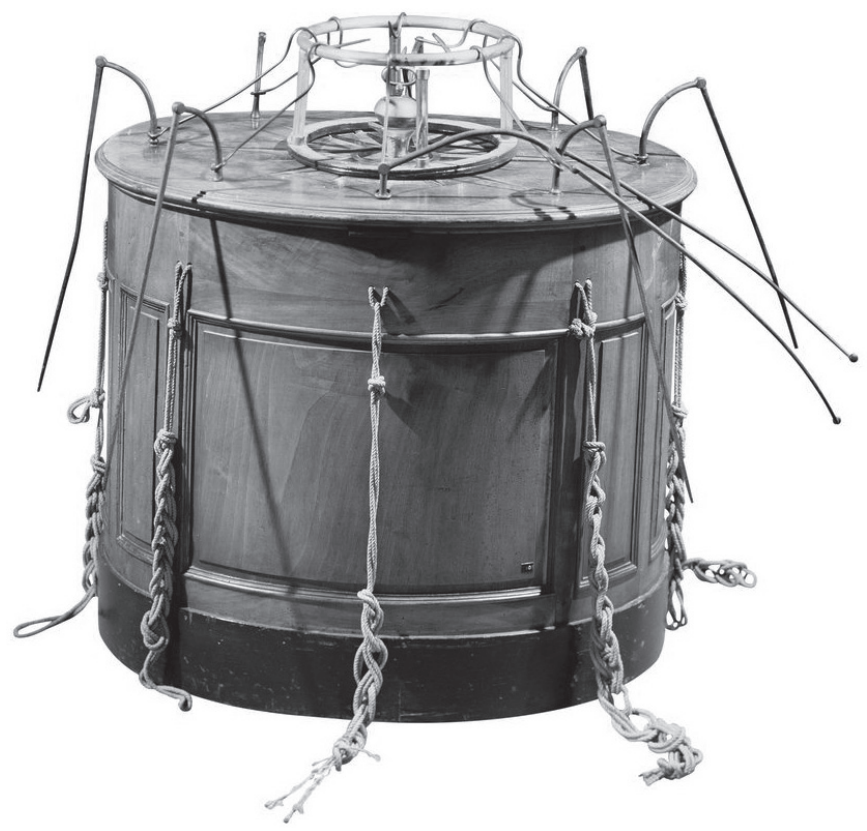

Figure 3. Mesmer's tub. Courtesy of Musée d'Histoire de la Médecine et de la Pharmacie, Lyon.

Gilibert stated that the goal of his experiments was to see if the effects of animal magnetism would not result from imagination (Gilibert, 1784, p. 24). As already mentioned, he emphasized that he made no experiments on the sick, for he first wanted to be certain of the effects of magnetism on healthy people. His mesmerist experiments were not aimed at defining how animal magnetism could be used to cure, but at defining how animal magnetism affects the human body. In that attempt, Gilibert declared that he took into consideration only the facts that he himself had observed. ${ }^{26} \mathrm{He}$ insisted on the necessity to be impartial in his experimentations: "The physician who wants to make up his mind wisely must listen to everyone, not belong to any party, and reason only based on what he has observed himself." ${ }^{27}$ This has to be done "without partiality, enthusiasm or prejudice." 28

\footnotetext{
26 "Vous connoissez, Monsieur, ma manière lente de raisonner, ne procédant que par des faits bien constatés [...]." (Gilibert, 1784, p. 45)

27 "Le médecin qui veut prendre un parti sage, doit tout entendre, n'être d'aucun parti, et ne raisonner que d'après ce quil a vu et observé lui-même [...]." (Gilibert, 1784, p. 35)

28 "sans partialité, sans enthousiasme et sans préjugé." (Gilibert, 1784, p. 23)
} 
Gilibert claimed that during the 25 years that he had practiced medicine, he had "learned to accept facts and inductions, only after having analyzed, compared and weighed them on the most severe scales" ${ }^{29}$ He was suspicious of physicians, even the most renowned, who only talked about their successes and not about their failures ${ }^{30}$ and declared that if he was wrong, he would retract his statements. ${ }^{31}$ Gilibert did not mention the exact number of experiments that he carried out, nor the number of persons on whom he conducted these experiments, but we know that he defined two kinds of experiments: 'emanation magnetism' (using devices) 32 and 'spontaneous magnetism' (without devices)'. Let us begin with the latter.

Out of the about 40 persons of different ages, on whom Gilibert carried out spontaneous magnetism experiments (Prost himself was one of them), some sensed sharp heat, especially on the stomach, some felt ear palpitations, anxiety, fear, syncope, pain. Some even asked Gilibert to stop the interventions. Gilibert noticed that, in general, it is possible to stop the heat by making a second pass in reverse on the places of the bodies that had been magnetized, provided that the hand muscles were relaxed (Gilibert, 1784, pp. 16-17). To make sure that magnetism was not an effect of imagination, Gilibert decided to magnetize people without their knowledge:

As my first subject I chose a woman, who, when magnetized three days before, had felt a light warmth, oppression, anxiety, sweat [...]. I had not warned her. While I was talking with her daughter about some medicine that her mother had to take, I stretched out my hand toward the mother, without her seeing me, and moved it from the top of her head to the middle of her back, following the spine. After the third pass (my hand was 18 inches from her) she abruptly cried out and turned to me: "Doctor, you magnetized me;

29 "j’ai appris à n’adopter les faits et les inductions, qu'après les avoir analysés, comparés, et pesés dans la balance du doute le plus sévère." (Gilibert, 1784, p. 2)

30 "Je connois trop bien l'histoire de notre art, pour ne pas savoir que, dans tous les tems, les plus grands praticiens eux-mêmes ont caché leurs malheurs pour ne nous parler que de leurs succès." (Gilibert, 1784, p. 64)

31 "Continuons à observer sans partialité, à annoncer avec courage ce que je croirai avoir bien vu: et en supposant que des observations plus multipliées me convainquent que j'ai attribué trop précipitamment à un agent inconnu les purs effets de l'imagination, avoir le courage, sans rougir, de me rétracter." (Gilibert, 1784, p. 72)

32 "Le magnétisme par effluvion ou émanation a différents appareils [...]." (Gilibert, 1784, p. 9) 
I felt burning heat from the top of my head down to the middle of my back. Feel my hands, I am all sweaty."33

And Gilibert saw that it was true. Gilibert also described how he had magnetized a sixteen-year-old girl at her request. Using 'spontaneous magnetism', he concentrated on the epigastric region. At the beginning, she said that she had felt nothing (although Gilibert "felt as if the tip of [his] finger was in flames"). Once the experiment was over and the girl was having dinner, she began to cry and felt great anxiety, which lasted for more than an hour. She was pale and felt tired for several days. Gilibert claimed that he magnetized seven other persons this way, with a sensory effect (Gilibert, 1784, pp. 18-19).

As to the emanation magnetism experiments (using devices), Gilibert carried out one on himself, using bottles and magnets: ${ }^{34}$

One has to choose from the magnet stones sold at the drugstore the little fragments which are most likely to be charged with iron filings. These are smashed and pulverized, boiled abruptly in a pound or two of water, after having let them macerate for a long time on hot ash, equal parts of the flower of sulfur and magnet powder. We let the liquid cool, and then we filter it using a thick cloth. We store this water in a bottle. To charge oneself very effectively, it suffices to wash one's hands with this water, then rub the epigastric area, the calves and the armpits. Then, it is sufficient to pass the finger along the large venous trunks. Then one may quickly feel considerable heat: the veins swell, the flesh puffs up, the skin takes on a brighter color. And if one continues to place the hand on the same spot for several times, such as on the arm, the thigh or the leg, one will quickly feel distinct tingling, which becomes even painful on some subjects, as I have experienced myself. If a person so charged, even a robust and healthy patient, puts his thumb on the epigastric area, precisely below the xiphoid ${ }^{35}$ cartilage, especially if

33 "Je choisis pour premier sujet, une Dame, qui, magnétisée trois jours auparavant, avoit éprouvé chaleur légère, oppression, anxiété, sueur [...] ; je ne l'avois pas prévenue. Parlant avec sa fille de quelques remèdes quielle devoit prendre, je dirigeai ma main très-tendue sur la mère, qui ne me voyoit point, depuis le sommet de la tête, jusqu'au milieu du dos, en suivant la colonne vertébrale; dès la troisième passe (ma main étoit distante de 18 pouces) elle sécria en se tournant brusquement: "Docteur, vous mavez magnétisée ; j'ai senti une chaleur brûlante depuis le sommet de la tête jusqu'au milieu du dos. Touchez mes mains, je suis toute en sueur." (Gilibert, 1784, p. 18)

34 Actually, in 1774, an Austrian Jesuit priest, the royal astronomer Maximilian Hell (1720-1792) had introduced Mesmer to a new form of treatment with magnets (Lanska \& Lanska, 2007, p. 302).

35 "Xiphoid process: the smallest of three parts of the sternum, articulating with the inferior end of the body of the sternum above and laterally with the seventh rib." (Mosby's Dictionary of Medicine, 2017, p. 1898) 
the other four fingers are slightly apart, and presses in the space of the false ribs, then the patient is quickly seized with astonishment, which is difficult to describe. He distinctly feels sharp heat penetrate his chest. His inhaling becomes deeper and more frequent, sometimes even difficult. They sense a kind of anxiety, the face becomes warmer and colored. The same experiment carried out on others, shows that the patients "turned pale and were about to faint. Almost all of them experienced stupor, a singular sensation in the bottom of the eye-socket, and as they said, their eyes were as if clouded" ${ }^{36}$

Gilibert warns that such experiments have caused many accidents, such as spasmodic suffocation with anxiety and fainting (Gilibert, 1784, p. 14).

He also described another emanation magnetism experiment carried out on himself using sulfur sticks:

I used sulfur in a cylindrical form, I held the sticks in my hand for a long time, I felt them crackle since the first minutes, and after an hour, I felt significant heat, my heart rate increased, and my pulse reached 4 beats above the normal. The following day I used six cylinders of sulfur, I applied one on the epigastric area, two under the armpits, two under the hamstring, and one on the perineum. I laid on my back with this strange device and slept, rather well, for three or four hours, but suddenly I woke up, feeling a

36 "Il faut choisir, parmi les pierres d'aimant qui se vendent chez les droguistes, les petits fragmens les plus susceptibles de se charger de limaille de fer; on les brocarde et on les pulvérise; on les fait bouillir brusquement dans une livre ou deux d'eau, après avoir laissé long-tems macérer, sur de la cendre chaude, partie égale de poudre d'aimant et de fleur de souffre. On laisse déposer par le refroidissement de la liqueur, après on décante pour la filtrer à travers un linge très-serré. On conserve cette eau dans une bouteille. Pour se charger d'une manière très efficace, il suffit de se laver les mains avec cette eau, de s'en frotter la région épigastrique, les jarrets et les aisselles. Dans cet état, il suffit de passer le doigt suivant l'étendue des grands troncs veineux; alors on sent promptement se développer une chaleur considérable; les veines seenflent, les chairs se boursoufflent, la peau prend un coloris plus vif, et si on continue plusieurs fois à repasser la main sur le même endroit, comme sur le bras, la cuisse ou la jambe, on ne tarde pas à sentir très-distinctement un picotement qui devient même douloureux sur quelques sujets, comme je l'ai éprouvé sur moi-même. Si une personne ainsi chargée, porte le pouce sur la région épigastrique, précisément au-dessous du cartilage xiphoide, chez une personne même robuste et bien portante, sur-tout si les quatre autres doigts, un peu écartés, pressent dans l'intervalle des fausses côtes; alors le sujet touché ne tarde pas à être saisi d'un étonnement difficile à exprimer, il ressent distinctement une chaleur vive qui pénètre dans la poitrine; les inspirations deviennent plus profondes et plus fréquentes, quelquefois même laborieuses, et occasionnent une espèce d'anxiété; le visage séchauffe et se colore; quelques-uns, au contraire, pâlissent et sont prêts à tomber en défaillance; presque tous éprouvent une stupeur, une sensation singulière au fond de l'orbite, et pour parler leur langage, ont les yeux couverts d'un nuage." (Gilibert, 1784, pp. 12-14) 
burning sensation in my guts ${ }^{37}$ and a strong headache. Checking my pulse, I found it accelerated with a cadence of twelve more beats per minute. The temporal arteries were beating with energy. Nevertheless I slept for another hour after having removed the sulfur sticks, but my sleep was very restless. I woke up several times as if I was suffocating. The next day I worked as usual until nine o'clock. I then felt a sharp shiver, followed by considerable spasms, anxiety and oppression. After trembling for three hours, the heat appeared that lasted for three hours, and ended with profuse sweating, during which I could not resist a sleep interrupted by headache. ${ }^{38}$

And Gilibert concluded: "I had enough with this experiment. I was not willing to do it again. Several of my acquaintances decided to have another try and felt, to a lesser degree, very similar symptoms" ${ }^{39}$

Gilibert also described another emanation magnetism experiment, using a jar:

I took a glass jar containing six pounds of water; I put in the bottom rather black iron filings, which had not lost their phlogiston; ${ }^{40}$ I poured water over it; I had a wooden cube floating above it, with a wire pierced through which went down to the filings; I tied a string to the upper end of the wire; I sealed everything, the string and the wire, using sealing wax. ${ }^{41}$ This string, twelve feet long, had a button of sealing wax at its end; I wrapped the string around me, placing the knot on the epigastrium. After an hour, I felt very intense heat; I noticed that my breath accelerated; my face was swollen, my

37 Gilibert wrote: "ardeur d'entrailles". "Ardeur: chaleur véhémente, chaleur extrême [...] se dit aussi de la chaleur âcre et piquante qu'on éprouve dans certaines maladies." (Dictionnaire de l'académie françoise, 1762, p. 97)

38 "je pris du soufre en cylindre, je tins les bâtons long-tems dans ma main, je les sentis crépiter dès les premières minutes, et après une heure je sentis une chaleur assez marquée; mon pouls battoit, par minute, quatre pulsations au-delà de l'état naturel. Le lendemain je pris six cylindres de soufre; je m'en appliquais un sur la région épigastrique, deux sous les aisselles, deux sous les jarrets, et un au périnée, je me couchai avec cet étrange appareil, et dormis, assez bien, trois ou quatre heures: mais je fus éveillé en sursaut, éprouvant une ardeur d'entrailles considérable et une grande douleur en tête. En me tâtant le pouls, je le trouvai plein, et accéléré de douze pulsations par minute, sur-tout les artères temporales battoient avec énergie; cependant je me rendormis une heure après que j’eus abandonné mes bâtons de soufre; mais mon sommeil fut très-agité; je m'éveillai plusieurs fois comme suffoqué. Le lendemain je travaillai à l'ordinaire jusqu'à neuf heures. Alors j’éprouvai un frisson vif, suivi de spasmes considérables, anxiétés et d'oppressions. Après avoir tremblé trois heures, la chaleur survint très-forte, dura trois heures, et fut terminée par une sueur abondante pendant laquelle je ne pus résister à un sommeil interrompu par la douleur de tête." (Gilibert, 1784, pp. 10-11)

"C'étoit assez pour moi de cette expérience, et je n'étois pas tenté de la renouveller. Plusieurs personnes de ma connoissance voulurent la répéter, et éprouvèrent, à un moindre degré, des symptômes très analogues." (Gilibert, 1784, p. 11)

41 Wax of Spain (“cire d'Espagne”). 
eyes burning with conjunctivitis, ${ }^{42}$ the pulse becoming better, harder and more rapid; overall the carotids and the temporal vibrated with vehemence; I began to feel the anxiety that always preceded palpitations of my heart, and I hastened to abandon this device. ${ }^{43}$

Gilibert believed that he was not strong enough to endure such experiments, and so he asked some of his friends to repeat them, and received the same results (Gilibert, 1784, p. 13).

\section{GILIBERT'S CONCLUSIONS ABOUT HIS EXPERIMENTS}

For Dr Gilibert, the experiments that he carried out proved that magnetism existed and rarely resulted from imagination (Gilibert, 1784, pp. 32-33). He noticed that, in general, magnetism had a stronger effect on women than it did on men, on the young more than the old, on the sanguine more than the phlegmatic (Gilibert, 1784, p. 16).

Also, magnetism confirmed the existence of vitalism for him:

Starting out with a simple and pure observation, we can see that there are distinct centers of vitality in the human body. The ideas develop in the head, the sensibility resides in the stomach area, and the third center of life is located at the base of the body, in the hypogastric area. Let's call the center of the brain the higher pole of the human body, and the generative organs - the lower pole of the body; the diaphragm, along with the surrounding nervous plexus, will be the equator of the human body. ${ }^{44}$

42 Gilibert wrote "conjonctivite engorgée".

43 "je pris un bocal de verre contenant six livres d'eau; je mis au fond de la limaille de fer bien noire, qui n'avoit point perdu son phlogistique, je versai de l'eau par-dessus; je fis surnager un cube de bois, traversé par un fil de fer qui plongeoit dans la limaille; j’attachai une ficelle à l'extrémité supérieure du fil de fer; je scellai le tout, la corde et le fil, avec de la cire d'Espagne. Cette corde, longue de douze pieds, avoit un bouton de cire d'Espagne à son extrémité ; je m'entourai le corps avec cette corde, arrêtant le næud sur l'épigastre. Après une heure, je sentis une chaleur très forte; je m'apperçus que ma respiration s'accéléroit; javois le visage boursoufflé, les yeux ardens, la concjonctivite engorgée, le pouls plus plein, plus dur, et plus accéléré ; sur-tout les carotides et les temporales vibroient avec vébémence, je commençai à sentir une anxiété qui précédoit toujours mes palpitations de cœur, et me hâtai d'abandonner cet appareil." (Gilibert, 1784, p. 11)

44 "En partant de la simple et pure observation, le corps humain présente des centres de vitalité bien distincts; la masse des idées se développe dans la tête; la sensibilité réside vers la région de l'estomac; et un troisième centre de vie réside à la base du corps, dans la région hypogastrique. Appelons le centre du cerveau le pôle supérieur du corps; les organes de la génération, le pôle inferieur; le diaphragme avec les plexus nerveux qui l'avoisinent, sera l'équateur du corps humain." (Gilibert, 1784, p. 36) 
Gilibert noticed that organs balance one another. If the equilibrium is perfect, then the health is good, but as soon as a single organ loses its vitality, the health worsens..$^{45}$ So he concluded that "all these facts prove that the body is governed by a principle of vitality which has three significant domains: the bulb of the brain, the diaphragm and the lower extremity of the back. ${ }^{46}$

During his experiments, Gilibert observed that emanation as well as spontaneous magnetism produced fever with pustular rashes ${ }^{47}$ and nervous fever. Magnetism reanimated the vital principle, giving tone and spirit to vessels, fibers and nerves. According to Gilibert, it was possible to increase or decrease the effects of magnetism at will. ${ }^{48}$ In this regard, magnetism could become a great therapeutic resource (Gilibert, 1784, p. 48).

Nevertheless, Gilibert estimated that magnetism would be harmful to the patient in half of the known diseases. He specified that if magnetism was useful for the diseases resulting from atony (debility) and fatigue, it would be harmful for those which are the result of some rigidity in the organs. ${ }^{49}$ In the case of acute diseases, where the vital principle is usually the strongest, magnetism would be the least useful, and only of some use in cases of debility which require the prescription of cordials, irritants, ${ }^{50}$ and tonics, but always acting very cautiously. ${ }^{51}$ In the case of chronic diseases, as well as in the rare cases of weakness, magnetism, by exciting a momentary fever, could possibly be useful. ${ }^{52}$

45 "Tous ces organes se contre-balancent entr'eux, de manière que lorsque l'équilibre est parfait, la santé est complette: si un seul organe a perdu de sa vitalité, la santé est altérée." (Gilibert, 1784, p. 37)

46 "Tous ces faits prouvent que le corps humain est régi par un principe vital qui a trois grands domaines : le bulbe du cerveau, le diaphragme et l'extrémité inferieure du dos." (Gilibert, 1784, p. 40)

47 Gilibert wrote "fièvre vasculeuse".

48 "J'observe d'abord que le magnétisme spontané, et par émanation, dirigé d'une certaine manière, excite tous les symptômes d'une fièvre vasculeuse, et d'une fièvre nerveuse, c'est à dire, quil ranime le principe vital, donne du ton, du ressort aux vaisseaux, aux fibres et aux nerfs; qu'on peut exciter ses effets à volonté, et les faire cesser lorsqu'on les croit superflus." (Gilibert, 1784, p. 48)

49 "il faut nécessairement que le magnétisme nuise dans la moitié des maladies connues. S'il est utile dans celles qui proviennent d'atonie, de relâchement, il sera nuisible dans celles qui reconnoissent pour principe la rigidité, le ressort des organes?' (Gilibert, 1784, p. 70)

50 "Irritants: name given to medicines that cause a pathological state on the surface that they are applied to as well as on other parts of the body." (Mérat \& Lens, 1831, p. 659)

51 "Dans les maladies aiguës, où, le plus souvent le principe vital réagit avec tant d'énergie que nous devons sans cesse travailler à modérer ses efforts, je crains que ce magnétisme ne puisse être employé avantageusement; que dans les cas plus rares; où l'affaissement, la foiblesse exigent nos cordiaux, nos irritans, nos toniques, je crois du moins qu'il faut beaucoup de savoir et de prudence." (Gilibert, 1784, p. 61)

52 "Quant aux maladies chroniques, le magnétisme, excitant une fière momentanée que l'on peut renouveller à volonté, nous promet beaucoup plus de ressources [...]" (Gilibert, 1784, p. 61). 
Gilibert warned that while magnetism elicited favorable feelings, they could be followed by sadness (Gilibert, 1784, p. 65). He also warned that some polyps of the heart ${ }^{53}$ may occur if crises (resulting in convulsions, suffocation, fainting) were too frequent. He then reminded that after frequent crises, the pulmonary artery dilates and causes soft tumors (Gilibert, 1784, p. 68).

Gilibert also noted that people who often convulsed, and for a long period of time, could present varices (dilated blood vessels) in the cerebral sinus. Some lethal aneurysms or tumors could also emerge because of the dilation of the arteries. The more violent the convulsions, the stronger the atony, he observed, as in the case of alcohol consumption. Finally, he warned that magnetism itself may cause diseases and even be lethal (Gilibert, 1784, pp. 68-69). It is worth noting that, next to Gilibert, also some other physicians warned against the dangers of magnetism in works published the same year (1784). Paul Mahon noted that it may be dangerous because of its influence on the nerves. ${ }^{54}$ Also, an Irish physician teaching at the Montpellier University, Michael O'Ryan (1784, pp. 13-14, 31), who observed a session of magnetism with a tub, was shocked and afraid by the scenes of hysteria he saw. He argued that the convulsions may be communicative, and cited similar cases that had occurred at the Royal Infirmary of Edinburgh in Scotland and at the hospital of Haarlem in the Netherlands (O’Ryan, 1784, pp. 21-23, 31).

Finally, Gilibert feared that if magnetism was practiced by people who know nothing about diseases, they could destroy the vital principle and this would be disastrous for the patient. ${ }^{55}$ It is worth noting that on the other side of the continent, in Lithuania, at the Vilnius Imperial University, some professors also took interest in animal magnetism. One of them, the eminent professor of medicine Joseph Frank (1771-1842), to whom magnetism was an expression of disorders in the nervous system, was also afraid that it would be practiced by charlatans (Bezliapovič et al., 2017, p. 251).

53 Gilibert wrote "concrétions polipeuses au cour". "Polyp: a small tumor-like growth that projects from a mucous membrane surface" (Mosby's Medical Dictionary, 2017, p. 1420).

54 "Le magnétisme animal ne produisant chez nous des changemens que par son action sur nos nerfs, il me semble bien diffcile de croire que cette action ne puisse jamais être trop forte." (Mahon, 1784, p. 12)

55 "Si le magnétisme est un agent puissant, comme on n'en peut douter, en examinant de sang-froid les phénomènes qu'il produit, ne doit-on pas craindre que, administré par des mains peu exercées, ou ce qui est pire, par gens ignorant l'art de distinguer les espèces de maladies, il ne devienne, sous leur direction, un agent destructeur du principe vital." (Gilibert, 1784, p. 67) 


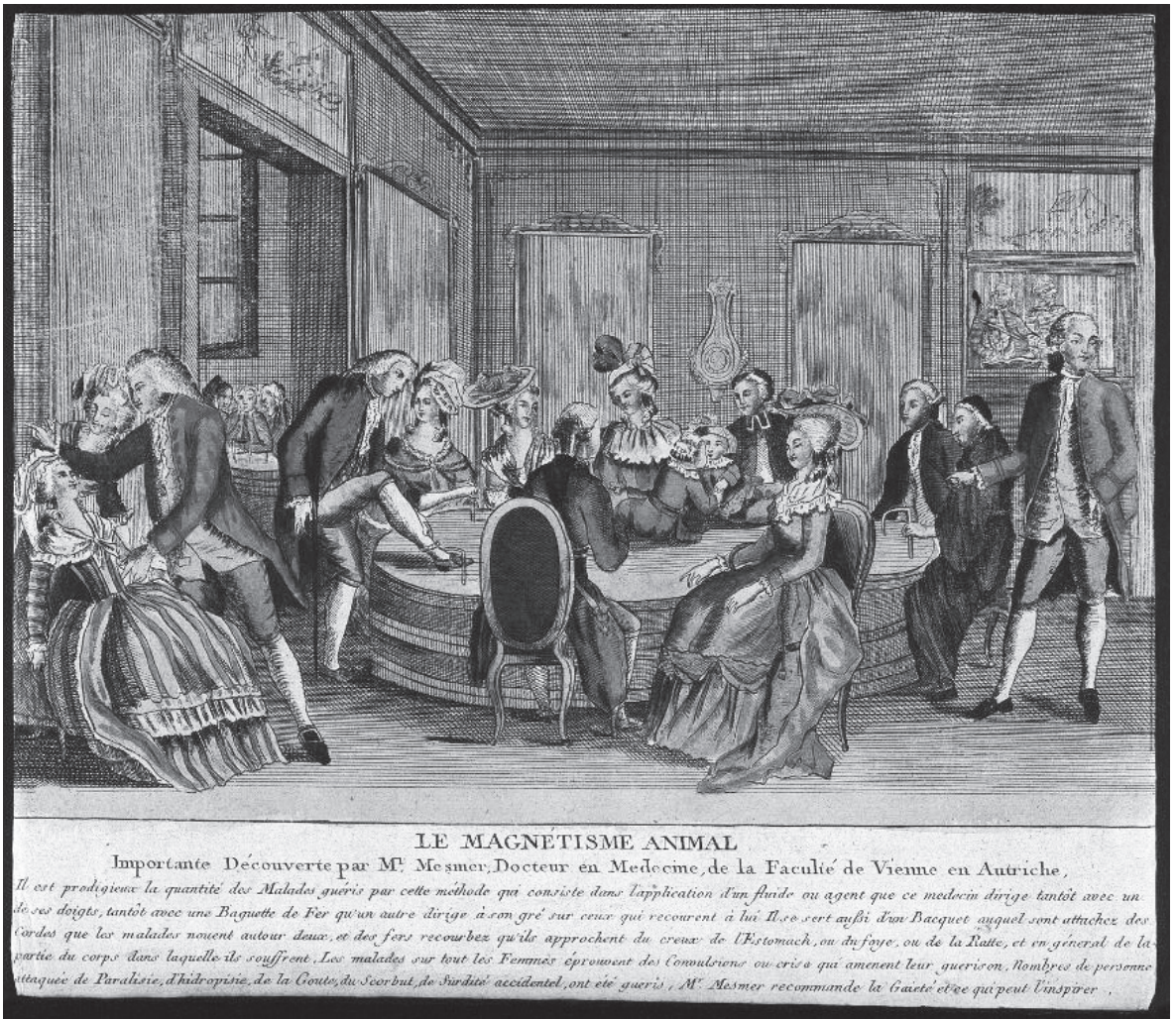

Figure 4. Le magnétisme animal. Drawing by Claude Louis Desrais (1746-1816)

(Wellcome Library no. 17918i).

Gilibert felt that experiments with magnetism on humans should only be carried out by physicians who cared for the public's welfare (Gilibert, 1784, p. 63). In a press article published in the winter of 1785 , Mesmer himself recognized the need for skilled magnetizers: "I do not simply have speculative truths to inform you about, but a very delicate practice to develop, which demands from those who practice it, a new kind of education". ${ }^{56}$

56 "Je n'ai pas simplement des vérités spéculatives à faire connoître, mais une pratique très délicate à développer, et qui exige de la part de ceux qui sy livrent une sorte d'éducation nouvelle." (Journal de Paris, 1785, p. 66) 


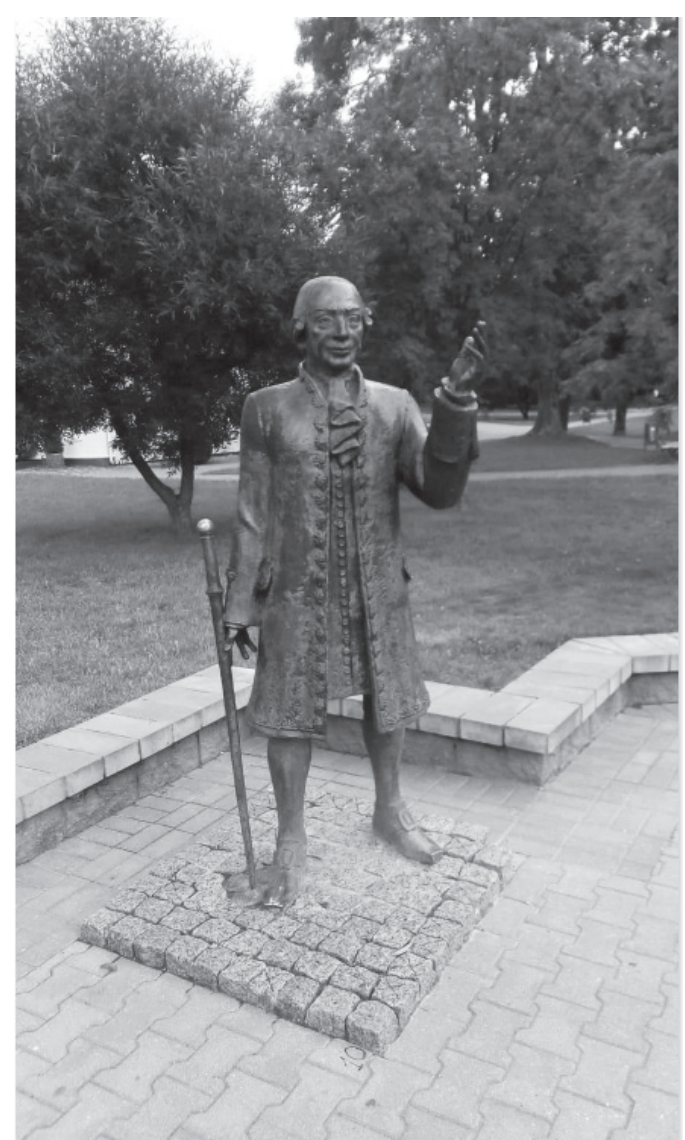

Figure 5. The statue of Dr Jean-Emmanuel Gilibert in Gilibert's Park, Grodno, Belarus. Photo by Aleksandr Feduta.

\section{Discussion and conclusion}

Dr Gilibert, as a typical man of the Age of Reason, wanted to observe everything himself, accepting nothing but well-established facts. After carrying out his experiments, he acknowledged that animal magnetism exists and may affect the body. In fact, this effect was so powerful, Gilibert argued, that although magnetism may be useful in the treatment of some diseases, it is basically harmful. Indeed, vitalists were fascinated by animal magnetism, for they saw in it a chance to enhance the effect of nature on the human body, the magnetizer being an intermediary between nature and the patient. In fact, one may wonder if the magnetizers did not go too far in acting on their patient's metabolism. More likely, they forced nature. In the 19th century, vitalism and mesmerism were both doomed to disappear. Vitalism because it was invalidated and mesmerism because it split into different trends (psychosomatic medicine, but also hypnotism, somnambulism, among others). Nevertheless, they both contributed to the evolution of science. Before reaching a significant discovery, science sometimes has to follow uncertain paths. Gilibert probably achieved no breakthrough in the field of magnetism, but following the trial-and-error methods to study the phenomenon of magnetism he set up a scientific approach that could be imitated by other researchers. His experiments, published with their outcomes, supported by the notoriety he had already 
gained in the field of medicine, contributed to the growing interest in mesmerist phenomena among a wider public.

\section{Bibliography}

Azouvi, Fr. (1976), 'Sens et fonction épistémologiques de la critique du magnétisme animal par les Académies,' Revue d'histoire des sciences, vol. 29, no. 2, pp. 123-142. https://doi.org/10.3406/rhs.1976.1389

Bailly, J. et al. (1784), Exposé des expériences qui ont été faites pour l'examen du magnétisme animal. Lu à l'académie des Sciences, par M. Bailly, en son nom et au nom de MM Franklin, Le Roy, de Bory et Lavoisier, le 4 septembre 1784, Paris: Moutard.

Barou du Soleil, P. A. (1784), Eloge de Monsieur Prost de Royer, ancien échevin et lieutenant général de Police de Lyon, etc, prononcé à l'ouverture des audiences de la sénéchaussée de Lyon, le 30 novembre 1784, Lyon, 1784.

Bergasse, N. (1781), Lettre d'un médecin de la faculté de Paris, à un médecin du collège de Londres, ouvrage dans lequel on prouve contre M. Mesmer, que le Magnétisme animal n'existe pas, La Haye.

Bezliapovič, Ž.; Sakalauskaitė-Juodeikienè, E.; Samsonė, V. G. \& Jatužis, D. (2017), 'Vitalinio magnetizmo praktika ir kritika XIX a. pr. Vilniuje,' Neurologijos seminarai, no. 4(74), pp. 247-256.

Biographie universelle (1823), Biographie universelle, ancienne et moderne, vol. xxxvi, Paris: L. G. Michaud.

Brack (1784), Histoire du magnétisme en France, de son régime, de son influence, Vienne \& Paris: Royez.

Brockliss, L. \& Jones, C. (1997), The Medical World of Early Modern France, Oxford: Clarendon Press.

Cambridge Dictionary (n.d.), 'Pseudo-science.' Retrieved from https://dictionary. cambridge.org/dictionary/english/pseudo-science [accessed Feb 2020]

Chertok, L. \& Stengers, I. (1992), A Critique of Psychoanalytic Reason, Hypnosis as a Scientific Problem from Lavoisier to Lacan, Stanford: Stanford University Press.

Darnton, R. (1968), Mesmerism and the End of the Enlightenment in France, Cambridge, MA: Harvard University Press.

Daszkiewicz, P. (1995), Polityka i przyroda: rzecz o Jean Emmanuelu Gilibercie, Warszawa: Neriton.

Dictionnaire de l'académie françoise (1762), quatrième édition, tome premier, Paris: veuve Brunet.

Dictionnaire de jurisprudence et des arrêts (1783), tome troisième, Lyon. 
d'Eslon, Ch. (1785), Observations sur le magnétisme animal, Londres \& Paris: Didot, Saugrain \& Clousier.

Doppet, A. (1784), Traité théorique et pratique du magnétisme animal, Turin: J. M. Briolo.

Ede, A. \& Cormack, L. (2007), A History of Science in Society, from the Scientific Revolution to the Present, vol. 2, 3rd ed., North York: Toronto Press.

Gilibert, J.-E. (1784), Apperçu sur le magnétisme animal, ou résultat des observations faites à Lyon sur ce nouvel agent, Genève.

Ignatovich, F. (2011), 'Zh. E. Zhiliber i grodnenskaia meditsinskaia akademiia (k 270-letiiu so dnia rozhdeniia),' Zhurnal Grodnenskogo gosudarstvennogo meditsinskogo universiteta, no. 2(34), pp. 85-90.

Inchbald, E. (1789), Animal Magnetism, a Farce of Three Acts as Performing at the Theatres-Royal of London and Dublin, Dublin: Lewis.

Journal de Paris (1785), no. 16, Dimanche, 16 janvier.

Jussieu, A. (1784), Rapport de l'un des commissaires chargés par le roi de l'examen du magnétisme animal, Paris: la veuve Hérissant, Théophile Barrois le jeune.

Lanska, D. \& Lanska, J. (2007), 'Franz Anton Mesmer and the rise and fall of animal magnetism: dramatic cures, controversy, and ultimately a triumph for the scientific method,' in H. Whitaker, C. U. M. Smith \& Finger, S. (eds.), Brain, Mind and Medicine: Essays in Eighteenth Century Neuroscience, New York: Springer-Verlag. https://doi.org/10.1007/978-0-387-70967-3_22

Lapassade, G. (1983), 'Les thérapies par la transe,' L’homme et la société, no. 65-66. https://doi.org/10.3406/homso.1982.2091

Lavoisier, A.-L. (1789), Traité élémentaire de Chimie, Paris: Cuchet.

Mahon, P. (1784), Examen sérieux et impartial du magnétisme animal, Londres \& Paris: Royez.

McGrew, R. E. \& McGrew, M. P. (1985), Encyclopedia of Medical History, New York: McGraw-Hill Book Company.

Mérat, F. \& de Lens, A. (1831), Dictionnaire universel de matière médicale et de thérapeuthique générale, tome troisième, Paris: J.-B. Baillière, Méquignon-Marvis.

Mesmer, A. (1779), Mémoire sur la découverte du magnétisme animal, Genève \& Paris: Didot.

Mosby's Medical Dictionary (2017), 10th ed., Saint Louis: Elsevier.

O'Ryan, M. (1784), Discours sur le magnétisme animal, lu dans une Assemblée du Collège des médecins de Lyon, le 15 septembre 1784, par M. O. Ryan de l'université de Montpellier, et professeur en médecine, agrégé au dit Collège, Dublin.

Parent, A. (2015), 'Prancūzų gydytojų medicinos mokslo paveldas Lietuvoje XVIII a. paskutiniame ketvirtyje,' in R. Šmigelskytė-Stukienè (ed.) XVIII a. Studijos, t. 2: Valstybè. Kultūra. Edukacija, Vilnius: Lietuvos istorijos instituto leidykla, pp. $122-146$. 
Parent, A. (2016), 'From the Montpellier faculty of medicine to the Grodno Royal School of Medicine: how Dr Jean-Emmanuel Gilibert applied medical vitalism to heal his Lithuanian patients,' in R. Šmigelskytè-Stukienė (ed.) XVIII a. studijos, t. 3: Iššükiai. Laiméjimai. Netektys, Vilnius: Lietuvos istorijos instituto leidykla, pp. 210-237.

Poissonnier, P. et al. (1784), Rapport des commissaires de la Société royale de médecine nommés par le roi pour faire l'examen du magnétisme animal, Paris: Moutard.

Prost de Royer, A. (1765), De l'administration municipale ou Lettres d'un citoyen de Lyon sur la nouvelle administration, Lyon.

Prost de Royer, A. (1778), Mémoires sur la conservation des enfants, Lyon: Aimé de la Roche.

Prost de Royer, A. (1784), Dictionnaire de jurisprudence et des arrêts, ou jurisprudence universelle des parlements de France et autres tribunaux, Lyon: Aimé de la Roche.

Reil, J. (1808), 'Fragmente über die Bildung des kleinen Gehirns im Menschen,' in Archiv für die Physiologie, vol. viii, no. 1.

Rey, R. (2000), Naissance et développement du vitalisme en France de la deuxième moitié du 18 e siècle à la fin du premier empire, Oxford: Voltaire Foundation.

Roger, J. (1993), Les sciences de la vie dans la pensée française au XVIIIe siècle, Paris: Albin Michel.

Segala, M. (2001), 'Electricité animale, magnétisme animal, galvanisme universel: à la recherche de l'identité entre l'homme et la nature,' Revue d'histoire des sciences, vol. 54, no. 1. https://doi.org/10.3406/rhs.2001.2109

Sławiński, S. (1925), 'Dr. Jan Emmanuel Gilibert, profesor i założyciel Ogrodu Botanicznego w Wilnie: przyczynek bio-bibliograficzny do historii Uniwersytetu Wileńskiego,' Ateneum Wileńskie, vol. 3, no. 9, pp. 8-45.

Spiquel, A. (1997), 'Mesmer et l'influence,' Romantisme, no. 98, pp. 33-40. https://doi.org/10.3406/roman.1997.4287

Vihalemm, R. (2019), A Story of a Science: On the Evolution of Chemistry, Special Issue of Acta Baltica Historiae et Philosophiae Scientiarum, vol. 7, no. 2. https://doi.org/10.11590/abhps.2019.2.01

Vila, A. (1997), Enlightenment and Pathology: Sensibility in the Literature and Medicine of Eighteenth-Century France, Baltimore: Johns Hopkins University Press.

Wellcome Library no. 17918i, 'Patients in Paris receiving Mesmer's animal magnetism therapy. Coloured etching after C-L. Desrais,' etching, with watercolor and gum arabic. Retrieved from https://wellcomecollection.org/works/fthv79zp [accessed Feb 2020]

Wellcome Library no. 45736i, 'Franz Anton Mesmer. Oil painting,' no. 45736i, oil on canvas; canvas 51 x $41 \mathrm{~cm}$. Retrieved from https://wellcomecollection.org/works/ tjrmetp2 [accessed Feb 2020] 
Williams, E. (1994), The Physical and the Moral: Anthropology, Physiology, and Philosophical Medicine in France, 1750-1850, New York: Cambridge University Press.

Williams, E. (2003), A Cultural History of Medical Vitalism in Enlightenment Montpellier, Burlington: Ashgate.

Wilson, L. (1992), Women and Medicine in the French Enlightenment: The Debate over Maladies des Femmes, Baltimore \& London: The Johns Hopkins University Press.

Dr Arnaud Parent is a lecturer of French language and French civilization at the Institute of Humanities of Mykolas Romeris University, Vilnius, Lithuania. As a historian, he carries out researches about the relationship between France and the Commonwealth of the Two Nations (Poland-Lithuania) in the 18 th century. He is currently writing the biography of Dr Jean-Emmanuel Gilibert. 